\title{
Change of Water Concentration in the Uterus of the Rat Following Relaxin Treatment
}

\author{
Hiroshi WADA and Masataka YuHARA \\ (Department of Animal Husbandry, Faculty of Agriculture, \\ Okayama University, Okayama, Japan) \\ (Received for Publication March 5, 1962)
}

Relaxin has been known to have some effects on water and glycogen contents ${ }^{1-3)}$ and phosphorylase activity ${ }^{4 /}$ in the uterus of small laboratory rodents. Softening and dilatation of the cervix caused by treatment with relaxin were also demonstrated in rats and mice $1,5,6\}$ sows $^{7}$, cows $^{8}$, and women ${ }^{9-11)}$. The reduction of tension in the cervix was associated with depolymelization of the ground substance and an increase in water content of the tissue ${ }^{1,7}$. Thus, the treatment of relaxin was followed by similar metabolic alterations in the tissues of both the uterus and the cervix. Essentially the same changes were observed also in the symphysial tissue of the guinea pig relaxed by administration of relaxin ${ }^{12)}$. Of these alterations, an increase of water in the tissue seemed particularly important to uterine hypertrophy and cervical softening.

Zarrow and Brennan reported an increased content of water in the uterus of the rat following treatment with relaxin ${ }^{8)}$. Jablonsky and Velardo also reported the action of relaxin of promoting uterine growth ${ }^{13-15)}$. The previous investigators, however, used mostly very young rats in their studies.

The present investigation was performed to observe changes in concentration of uterine water in estrogen-primed, spayed mature rats following single injection of relaxin.

\section{Materials and Methods}

Thirty-five mature female albino rats, weighing 150 to $180 \mathrm{~g}$, were spayed at least 2 weeks prior to the treatment of hormone, and divided equally into 7 groups, A to G. Four groups, $A$ to $\mathrm{D}$, of rats were injected daily for 4 days with $3 \mu \mathrm{g}$ of estradiol benzoate in $0.1 \mathrm{~m} l$ of sesame oil. On the fifth day, group A was killed, without injecting relaxin, to serve as control. The other groups, B to D, were injected subcutaneously with 30 guinea pig units (GPU) of relaxin preparation dissolved in $0.1 \mathrm{~m} l$ of water, and killed 6,12 , and 24 hours, respectively, following the injection of relaxin.

Groups $\mathrm{E}$ to $\mathrm{G}$ of rats were given no pretreatment of estrogen. Group E served as ovariectomized control. The other groups, $F$ and $\mathrm{G}$, were injected with $30 \mathrm{GPU}$ of relaxin and killed 6 and 12 hours, respectively, after injection. The relaxin preparation used was Releasin W $1164 \mathrm{~A}$ Lot 8 , assayed $150 \mathrm{GPU}$ per $\mathrm{mg}$.

At necropsy the animals were decapitated under ether anesthesia and bled. Immediately after killing, the uterus was removed and made free from such serous membrane as the mesentery. To eliminate fluid from its lumen and surface, the uterus was incised longitudinally and blotted on bibulous paper. It was then weighed, dried in an oven at $100^{\circ} \mathrm{C}$ for 2 days, and reweighed. The water content of the uterine tissue was calculated from these two weights.

\section{Results and Discussion}

Data obtained in this study are shown in Table 1. In group A of rats receiving estrogen alone, the average water content of the uterus was 80.7 per cent. In group $B$, the average 
water content of the uterine tissues was 82.4 per cent 6 hours following the injection of relaxin, the increase being significant as compared with the control group $A(P=0.01)$. Thereafter, average uterine water decreased gradually. In group $C$ and $D$, it was 81.3 and 80.3 per cent 12 and 24 hours, respectively, following the injection of relaxin. The water content at 24 hours showed a significant decrease as compared with that at 6 hours $(P=0.001)$ and that at 12 hours $(P=0.05)$.

In group $\mathrm{E}$ of ovariectomized rats receiving no pretreatment of estrogen, the water content of the uterus averaged 78.2 per cent. In groups $F$ and $G$ of non-estrogenized, ovariectomized rats, the uterine water content following the injection of relaxin remained stationary at the same level as in the control group $\mathrm{E}$ of ovariectomized rats.

Table 1. Changes in water content of the uterus in estrogenized, spayed rats following single injection of $30 \mathrm{GPU}$ of relaxin preparation.

\begin{tabular}{|c|c|c|c|c|c|c|c|c|}
\hline \multirow{2}{*}{$\begin{array}{l}\text { Experi- } \\
\text { mental } \\
\text { group* }\end{array}$} & \multicolumn{3}{|c|}{ Ttreatment } & \multirow{2}{*}{$\begin{array}{c}\text { Autopsy } \\
\text { Hours } \\
\text { after } \\
\text { relaxin } \\
\text { injection }\end{array}$} & \multirow{2}{*}{$\begin{array}{c}\text { Av. } \\
\text { body } \\
\text { wt. } \\
(g)\end{array}$} & \multicolumn{3}{|c|}{ Uterus } \\
\hline & & & $\begin{array}{l}\text { Relaxin } \\
\text { (GPU) }\end{array}$ & & & $\begin{array}{l}\text { Av. } \\
\text { wet. } \\
\text { wt. } \\
\text { (mg) }\end{array}$ & $\begin{array}{l}\text { Av. } \\
\text { dry } \\
\text { wt. } \\
\text { (mg) }\end{array}$ & $\begin{array}{c}\text { Water } \% \\
\text { Mean } \pm \text { S.E. }\end{array}$ \\
\hline A & 3 & 4 & 0 & 0 & 150 & 348 & 67 & $80.7 \pm 0.2$ \\
\hline B & 3 & 4 & 30 & 6 & 157 & 420 & 74 & $82.4 \pm 0.3$ \\
\hline C & 3 & 4 & 30 & 12 & 163 & 358 & 67 & $81.3 \pm 0.4$ \\
\hline D & 3 & 4 & 30 & 24 & 157 & 319 & 63 & $80.3 \pm 0.1$ \\
\hline $\mathrm{E}$ & - & - & - & - & 154 & 162 & 34 & $78.2 \pm 0.5$ \\
\hline$F$ & - & - & 30 & 6 & 151 & 165 & 35 & $78.3 \pm 0.6$ \\
\hline G & - & - & 30 & 12 & 158 & 162 & 35 & $77.9 \pm 0.6$ \\
\hline
\end{tabular}

* Each group consisted of 5 rats.

$\begin{array}{cc}\text { Groups tested } & \text { P value } \\ \text { A-B } & 0.01 \\ \text { B-D } & 0.001 \\ \text { C-D } & 0.05 \\ \text { E-A } & 0.01\end{array}$

Thus, the uterine water content increased rapidly. The maximum hydration of the uterus was shown 6 hours following the injection of relaxin. The increased water content of the uterine tissue seemed to persist for about one day.

The changes in uterine water content elucidated in this experiment coincided roughly with those reported by previous authors ${ }^{1,16}$ in mice and rats. Wada and Turner ${ }^{21}$ reported the interaction of relaxin and ovarian steroid hormones on uterine growth in rats, demonstrating that relaxin augmented the promoting effect of estrogen on uterine growth. The present data also indicate that synergism of estrogen is necessary for relaxin to display its action on the uterus of spayed rats. In this regard, however, Zarrow and Brennan ${ }^{8)}$ concluded that no pretreatment with estrogen was necessary for relaxin to exercise its action on the water content of the uterine tissue. The animals used by them were intact rats 24 days of age. The Rudimentary ovaries of these animals might have been involved in the uterine hydration, synergistically with relaxin. There seems to be a possibility that even if the ovary is rudimentary, it can still function temporarily when any exogenous stimulant potentiates an ezymatic system in the tissue of the ovary. This supposition seems to be supported by the fact that vaginal opening has been noted in some relaxin-treated rats as early as 33 days of age and that the uterus was sensitive to extremely small doses of relaxin in rats 28 to 31 days of age $e^{18,15)}$. 


\section{Uterine Water and Relaxin}

It was also reported that Cervilaxin, a purified relaxin preparation, alone produced a marked softening of the cervix which allowed easy and rapid dilatation of the cervical canal with concomitant reduction in traumata to mother and infant ${ }^{9}$. In the case of such women, however, it is obvious that the ovary was intact and that endogenous estrogen acted in concert with exogenous relaxin.

No effect of relaxin was indicated on an increase in water content of the uterus of spayed rats receiving no estrogen treatment. This does not mean that estrogen is necessary for all physiological actions of relaxin. For example, relaxin alone produced an increase in active phosphorylase, a decrease in total phosphorylase, and an increase in the ratio of active to total phosphorylase in the uterus of rats ${ }^{4}$. In conclusion, so far as uterine water content is concerned, synergism of estrogen is required for relaxin to show its action. If estrogen is given, the presence of the ovary itself is not necessary for relaxin to exhibit its action.

Moreover, if relaxin were gonadotropin, the ovary would mediate between the effect of relaxin and the reproductive organs. Since relaxin acts in the absence of the ovary, it is not. a gonadotropin. This is also consistent with the conclusion drawn by previous investigators ${ }^{18)}$.

\section{Summary}

Experiments were performed to investigate changes in water content of the uterine tissue in estrogen-primed, spayed mature rats following injection of a single dose of relaxin. Uterine water content increased rapidly. The hydration of the uterus reached its maximum 6 hours. and then decreased gradually to its initial level about one day following a single subcutaneous injection of 30 guinea pig units of relaxin in water. Relaxin alone, however, had not any effect on uterine water content. Thus, relaxin increased uterine water content synergistically with estrogen. The nature of relaxin was also discussed.

\section{Acknowledgments}

The authors are greatly indebted to Dr. Robert L. KROC, of the Warner-Chicott Research Laboratories, Morris Plains, N.J., U.S.A., for his supply of the relaxin preparation.

\section{References}

1) Kroc, R.L., B.G. Steinetz and V.L. Beach Ann. N.Y. Acad. Sci., 75: 942, 1959.

2) WadA, H., and C.W. Turner Endocrinol., 68: 1059, 1961.

3) Zarrow, M.X., and D.M. Brennan Proc. Soc. Exp. Biol. \& Med., 95: 745, 1957.

4) Schmidr, J.E., and S.L. Leonard Endocrinol., 67: 663, 1960.

5) Steinetz, B.G., V.L. BEACH and R.L. Kroc ibid., 61: 271, 1957.

6) Zarrow, M.X., and J. Yochim Endocrinol., 69: 292, 1961.

7) Zarrow, M.X., G.M. Neher, D. Sikes, D.M. Brennan and J.F. Bullard Am. J. Obstet. Gynecol., 72: 260, 1956.

8) GrahaM, E.F., and A.E. Dracy J. Dairy Sci., 36: 772, 1953.

9) Birnberg, C.H., and M.M. Abitbol Obstet. \& Gynecol., 10: 366, 1957.

10) Eichner, E., C. Waltner and M. Goodman Am. J. Obstet. Gynecol., 71: 1035, 1956.

11) Stone, M.L., A. Sedlis and M. Zuckerman ibid., 76, 544, 1958.

12) Frieden, E.H., and F.L. Hisaw Endocrinol., 48: 88, 1951.

13) JABLONSKI, W.J.A., and J.T. Velardo ibid., 61: 474, 1957.

14) and - Anat. Rec., 127: 423, 1957.

15) - and Proc. Soc. Exp. Biol. \& Med., 98: 36, 1958.

16) Steinetz, B.G., V.L. BeAch and R. L. KRoc Recent Progress in the Endocrinology of Reproduction, Academic Press, New York, p. 389, 1959. 


\title{
リラキシン注射後のラッテ子宮の水分量の変化
}

\author{
和田宏・湯 原正高 \\ (岡山大学宸学部畜産学科)
}

\begin{abstract}
ェストロジェン注射・卵巣割去の成熟ラッテにホいて リ ラキシン注射後の子宮組織の水分量の変化を研究し
\end{abstract} 亦.

30GPU (モルモット単位) のリラキシン水溶液荤 1 回，友下注射寸ると，子宮の水分量は急速に增加し，6 時間で最大に達したが，その後，徐々に減少して，的 1
日で最初の量にもどつた。このようリラキシンは， エ ストロジェンと協同的に働いて，子宫の水分量を壃加さ

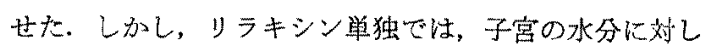

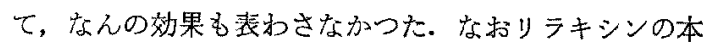
性についても諭僮した。 